\title{
MAMMALS FROM THE SALICAS FORMATION (LATE MIOCENE), LA RIOJA PROVINCE, NORTHWESTERN ARGENTINA: PALEOBIOGEOGRAPHY, AGE, AND PALEOENVIRONMENT
}

\author{
DIEGO BRANDONI1, GABRIELA I. SCHMIDT1, ADRIANA M.CANDELA2, JORGE I. NORIEGA1, ERNESTO BRUNETTO1, \\ AND LUCAS E FIORELLI3.
}

1Laboratorio de Paleontología de Vertebrados, Centro de Investigaciones Científicas y Transferencia de Tecnología a la Producción (CICYTTP-CONICET), Diamante 3105, Argentina.dbrandoni@cicyttp.org.ar, gschmidt@cicyttp.org.ar, cidnoriega@infoaire.com.ar, ebrunetto@yahoo.es

2División Paleontología Vertebrados, Museo de La Plata, La Plata 1900, Argentina. acandela@fcnym.unlp.edu.ar

3Departamento de Geociencias, Centro Regional de Investigaciones Científicas y Transferencia Tecnológica (CRILAR-CONICET), 5301 Anillaco, Argentina. Ifiorelli@ crilar-conicet.com.ar

\begin{abstract}
This study analyzes a collection of fossil mammals from the Salicas Formation in the El Degolladito area, La Rioja Province, Argentina. The materials reported herein were recovered from two sites (site 1 and site 2) and are: Macrochorobates Scillato-Yané, Chasicotatus Scillato-Yané, and Hoplophorini indet. (Xenarthra, Cingulata); Paedotherium minor Cabrera, cf Pseudotypotherium Ameghino (Notoungulata, Typotheria); Neobrachytherium Soria (Litopterna, Lopholipterna); Orthomyctera Ameghino, cf. Cardiomys Ameghino, Lagostomus (Lagostomopsis) Kraglievich, and Octodontidae indet. (Rodentia, Caviomorpha). This new mammalian assemblage, together with one previously recorded, has several taxa in common with mammalian associations from Central Argentina (i.e., La Pampa Province). Among those coming from Northwestern Argentina, the major affinity is with the El Jarillal Member (Chiquimil Formation) and then the Andalhuala Formation (both in Catamarca Province). The Salicas Formation fauna is considered as latest Miocene in age until new fossil discoveries and radioisotopic dates allow a better calibration. The fossil biota and geological data suggests that the Salicas Formation was deposited in flatlands, under warm and dry conditions. This environment was dominated by open grasslands, with forested areas near rivers and lagoons.
\end{abstract}

Key words. Mammals. Paleobiogeography. Paleoenvironment. Salicas Formation. Neogene. Northwestern Argentina.

Resumen. MAMÍFEROS DE LA FORMACIÓN SALICAS (MIOCENO TARDÍO), PROVINCIA DE LA RIOJA, NOROESTE DE ARGENTINA: PALEOBIOGEOGRAFÍA, EDAD Y PALEOAMBIENTE. El objetivo de esta contribución es analizar una colección de mamíferos fósiles procedentes de la Formación Salicas en el área de El Degolladito, provincia de La Rioja, Argentina. El material aquí reportado fue recolectado en dos sitios (sitio 1 y sitio 2). Los mamíferos registrados son: Macrochorobates Scillato-Yané, Chasicotatus ScillatoYané, y Hoplophorini indet. (Xenarthra, Cingulata); Paedotherium minor Cabrera, cf Pseudotypotherium Ameghino (Notoungulata, Typotheria); Neobrachytherium Soria (Litopterna, Lopholipterna); Orthomyctera Ameghino, cf. Cardiomys Ameghino, Lagostomus (Lagostomopsis) Kraglievich, y Octodontidae indet. (Rodentia, Caviomorpha). La asociación de mamíferos presentada, junto con otra registrada previamente, tiene varios taxones en común con asociaciones de mamíferos del área central de Argentina (i.e., La Pampa). Entre aquellas del Noroeste de Argentina, su mayor afinidad se da con las del Miembro El Jarillal (Formación Chiquimil) y la Formación Andalhuala (ambas ubicadas en la provincia de Catamarca) que con cualquier otra fauna Miocena o Pliocena del Noroeste de Argentina. La Formación Salicas es considerada de edad Miocena tardía hasta que nuevos registros fósiles y dataciones radiosotópicas permitan una mejor calibración. La información provista por la biota fósil y la interpretación geológica sugieren que la Formación Salicas pudo depositarse en planicies bajo condiciones climáticas cálidas y secas. Este ambiente estuvo probablemente dominado por pastizales y áreas forestadas cercanas a ríos y lagunas.

Palabras clave. Mamíferos. Paleobiogeografía. Paleoambiente. Formación Salicas. Neógeno. Noroeste de Argentina.

Chronology of the Neogene mammal-bearing terrestrial deposits from Argentina has been traditionally based on correlation of its faunal content because of the paucity of available radiometric or paleomagnetic data. Neogene units of Northwestern Argentina are uniquely complete and span almost the entire late Miocene-early Pleistocene, from about $9 \mathrm{Ma}$ to less than $2 \mathrm{Ma}$ (Marshall et al., 1984; Reguero et al., 2007; Reguero and Candela, 2011). Although this region has a less formalized mammalian biostratigraphic/biochrono- logic scheme than others (e.g., the Atlantic Coast of Buenos Aires Province and the central Pampean region; see Cione and Tonni, 1999, 2005; Verzi et al., 2008), recent studies have correlated the late Pliocene-early Pleistocene sequences of Northwestern Argentina to those exposed along the Atlantic coast of Buenos Aires (Reguero et al., 2007; Reguero and Candela, 2011). Mammal-bearing rocks of the late Miocene-Pliocene occur extensively in Northwestern Argentina (i.e., Catamarca, Tucumán, Jujuy, Salta, and La Rioja prov- 
inces). Several localities at Catamarca and Jujuy have Miocene-Pliocene outcrops that have been extensively studied from geological and paleontological points of view, focussing mainly on their fossil mammal content. Neogene mammals from La Rioja Province have remained relatively unexplored compared to others which are geographically and coeval nearby units (Chiquimil, Andalhuala, and Corral Quemado formations). Georgieff et al. (2004) described mammals collected in the Desencuentro Formation (southeastern La Rioja); Tauber (2005) recorded many taxa from the Salicas Formation; Rodríguez Brizuela and Tauber (2006) analyzed the fossil mammals from the Toro Negro Formation, in the northwest of the province; Krapovickas et al. (2009) studied vertebrate tracks and invertebrate traces from the Toro Negro Formation; and Krapovickas and Nasif (2010) studied dinomyid tracks from the Vinchina Formation.

For the Salicas Formation, Tauber (2005) mentioned the presence of several genera of Cingulata (e.g., Macrochorobates Scillato-Yané, 1980; Proeuphractus Ameghino, 1886; Chaetophractus Fitzinger, 1871; Eosclerocalyptus Ameghino, 1919), Rodentia (e.g., Neophanomys Rovereto, 1914; Lagostomus Brookes, 1828; Orthomyctera Ameghino, 1889; Potamarchus Burmeister, 1885), and Notoungulata (e.g., Protypotherium Ameghino, 1887; Pseudotypotherium Ameghino, 1904; Hemihegetotherium Rovereto, 1914; Tremacyllus Ameghino, 1891).

The aim of this contribution is to analyze a new collection of fossil mammals from the Salicas Formation, and discuss the systematics of the recovered taxa and their biochronological, paleobiogeographical, and paleoenvironmental significance in conjunction with information previously known for the unit.

\section{MATERIALS AND METHODS}

The limits and extent of the Salicas Formation were
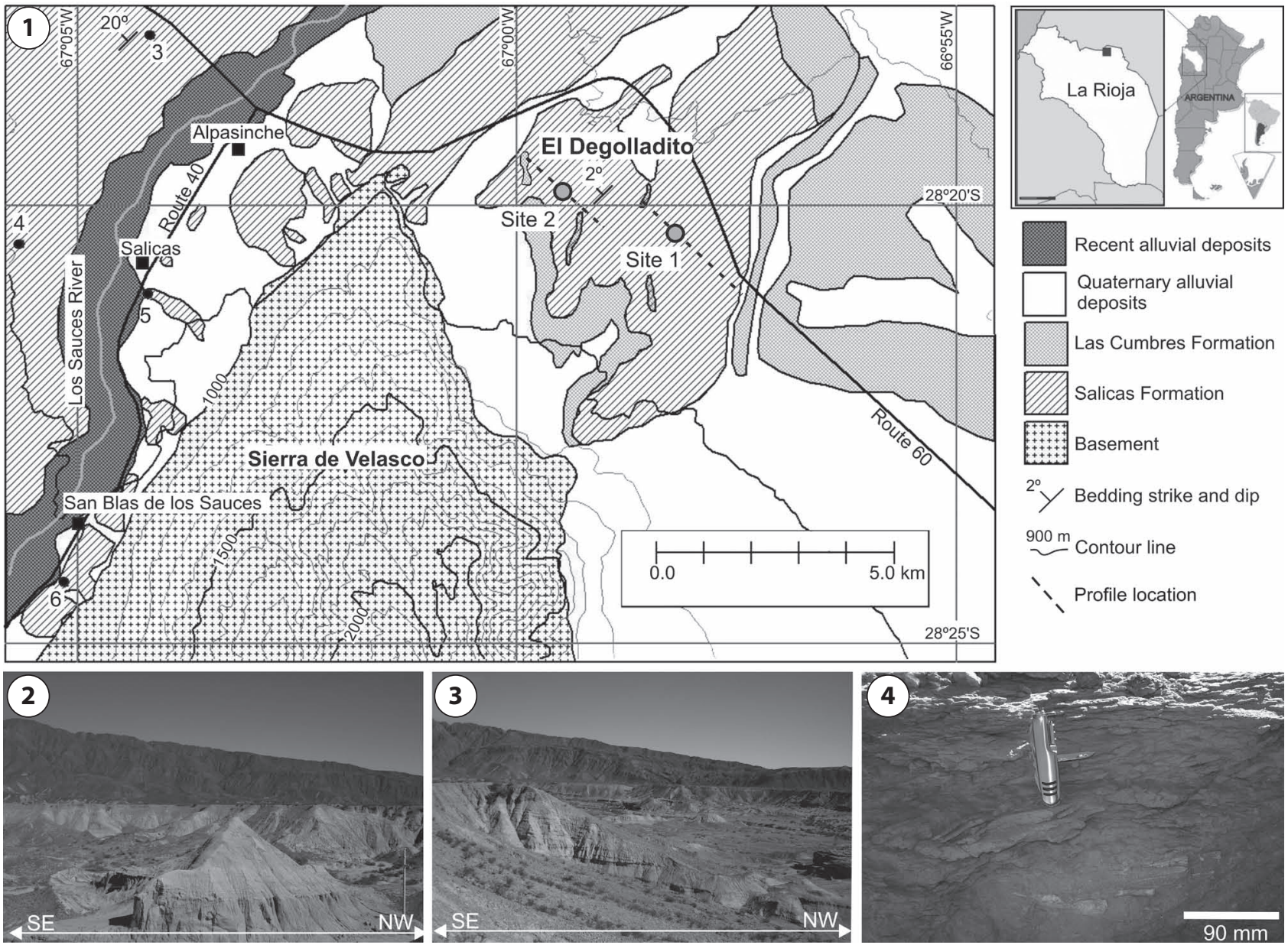

Figure 1. Study area/ área de estudio. 1, Geological map including fossiliferous sites (1-2, grey circles) and points of sedimentological and stratigraphic observation (3-6, black circles)/ mapa geológico que incluye los sitios fosiliferos (1-2, círculos grises) y puntos de observación sedimentológicos y estratigráficos (3-6, círculos negros). 2, site/ sitio 1. 3, site/ sitio 2. 4, Detail of structured sandstones including fossil material in site $2 /$ detalle de areniscas estructuradas incluyendo material fósil en sitio 2. 
studied through analysis of satellite images and field surveys. Grain size, sedimentary structures, and stratigraphic relationships were observed in the field. The stratigraphic column was analyzed in two cross-sections: site 1 -which was already studied by Tauber (2005) — and site 2 (Fig.1.1). Photographs allowed complementary observations for interpreting the geometric relations between lithostratigraphic units (Fig.1.2-3). Thickness of strata was calculated by trigonometry in considering the inclination of strata package —about $2^{\circ}$ in the El Degolladito area according to Tauber (2005) — and estimating the elevation differences between the sites with Digital Elevation Models (SRTM- 90m). Sedimentary facies were recognized in the field and classified following Miall's criterion (Miall, 1990). Collected materials were identified by comparison with specimens housed at the Museo Argentino de Ciencias Naturales "Bernardino Rivadavia" and the Museo de La Plata. The specimens described herein are deposited in the Departamento de Geociencias, Centro Regional de Investigaciones Científicas y Transferencia Tecnológica, Anillaco, La Rioja, Argentina (CRILAR Pv).

\section{GEOGRAPHIC AND STRATIGRAPHIC CONTEXT}

The north central region of La Rioja Province is characterized by a range and bolson system (internal basins enclosed by mountains) that was deformed during the late Cenozoic exposing Paleozoic and Neogene units. The Neogene sediments from the South of Pipanaco bolson include two lithologic units: the Salicas (lower) and the Las Cumbres (upper) formations (Socic, 1972, Bossi et al., 2001).

The Salicas Formation (Sosic, 1972) outcrops are along the eastern and western flanks of the northern portion of the Velasco range (Fig. 1.1). On the western slope of the range, the sedimentary unit overlies the granitic basement in nonconformity (Bossi et al., 2009), being their contact tectonic in origin (Sosic, 1972). The eastern side of the range is abrupt, representing the active mountain front. Quaternary alluvial fans cover the contact with the basement (Fig. 1.1). According to surface exposures, Sosic (1972) estimated the thickness of the Salicas Formation in 600-800 $\mathrm{m}$ at the southern end of Pipanaco bolson, whereas Bossi et al. (2009) estimated it in $440 \mathrm{~m}$ near the village of Alpasinche. The Salicas Formation is overlain by the Las Cumbres Formation (Plio-Pleistocene in age) (Fig. 1.1, 2), which is composed by gravels and coarse sands. The two units are separated by an angular unconformity (Bossi et al., 2007, 2009).

Considering the integrated stratigraphic section, the
Salicas Formation is dominated by massive fine sands and sandstones $(\mathrm{Sm})$ and clayey silts and siltstones $(\mathrm{Fm})$, which are reddish ochre in color alternating with clearer yellowish grey interstratified beds. These sediments are amalgamated in tabular banks with horizontal stratification. Thin strata of coarse sand and fine gravel and well-defined levels of white tuffs have also been identified in eastern outcrops at the Villa Mazán-Villa Mervil area (Bossi et al., 2009). The grade of lithification by calcareous cement is variable. Pedogenic features are evidenced by the presence of continuous calcrete levels.

Tauber (2005) studied the Salicas Formation and collect-
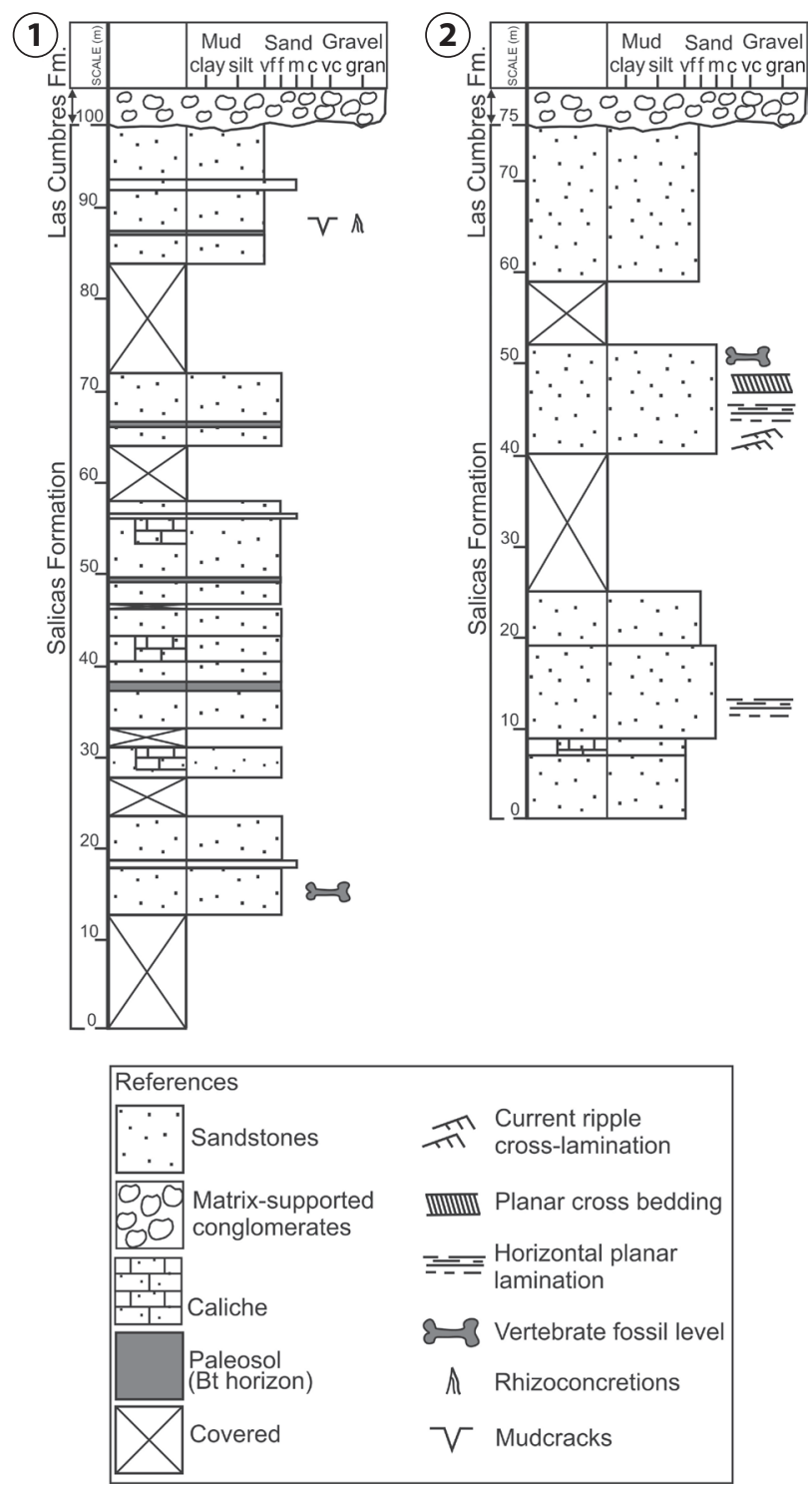

Figure 2. Stratigraphic profile of El Degolladito/ perfil estratigráfico de El Degolladito. 1, site/ sitio 1 (modified from/ modificado de Tauber, 2005). 2, site/ site 2. 
ed fossil vertebrates from La Cortadera and El Degolladito area, near the village of Alpasinche. Our study was also performed in the El Degolladito area, particularly at two sites:

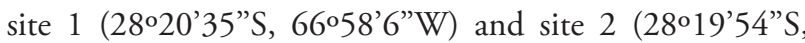
66059"21"W) (Fig. 1.1-3). Considering that in the El Degolladito area the strata dip is approximately $2^{\circ}$ toward the northwest (see Tauber, 2005), the set of these deposits along $5 \mathrm{~km}$ is estimated in $175 \mathrm{~m}$ thick (Fig. 2). The $100 \mathrm{~m}$ thick basal column corresponds to the site 1 (Fig. 2.1), and the $75 \mathrm{~m}$ thick upper deposits belong to the site 2 (Fig. 2.2). In this zone, the basal levels are exposed toward the southeast, whereas the upper levels appear to the northwest (Fig. $1.2-3)$.

At site 1 (Fig. 2.1), Tauber (2005) identified rhizoconcretions, carbonatic fill of mudcracks, and darker argillaceous levels, which were interpreted as Bt horizons of paleosols. Most of the fossils studied by Tauber (2005) and those reported herein from this site come from basal strata (e.g., level 2 of Tauber, 2005). At site 2 (Fig. 2.2), the fossiliferous levels correspond to structured sandstones with ripples, thin parallel bedding (Sh), and cross-bedding structures (Sp) (Fig. 1.4). The fossil materials from this site were recovered from the middle part of the upper stratigraphic section (Fig. 2.2).

\section{SYSTEMATIC PALEONTOLOGY}

Class Mammalia Linnaeus, 1758

Superoder Xenarthra Cope, 1889

Order Cingulata Illiger, 1811

Family Dasypodidae Gray, 1821

Subfamily Euphractinae Pocock, 1924

Tribe Euphractini Pocock, 1924

Genus Macrochorobates Scillato-Yané, 1980

Type species. Proeuphractus scalabrinii Moreno and Mercerat, 1891.

\section{Macrochorobates sp.}

Figure 3.1-2

Referred material. CRILAR Pv 420: a fixed and a moveable osteoderm (Fig. 3.1-2).

Procedence. Site 2 of El Degolladito area, La Rioja Province (Fig. 1.1, 2.2).

Remarks. The species of Macrochorobates differ by the size of the osteoderms and the convexity of the peripheral figures (Esteban et al., 2001; Urrutia et al., 2008). Tauber (2005) pointed out the record of Macrochorobates scalabrinii (Moreno and Mercerat, 1891) from the Salicas Formation.
Tribe Eutatini Bordas, 1933

Genus Chasicotatus Scillato-Yané, 1979

Type species. Chasicotatus ameghinoi Scillato-Yané, 1979.

\section{Chasicotatus sp.}

Figure 3.3

Referred material. CRILAR Pv 428: a fixed osteoderm (Fig. 3.3).

Procedence. Site 2 of El Degolladito area, La Rioja Province (Fig. 1.1, 2.2).

Description. The osteoderm is smooth (not rugose). The central figure carries a marked keel surrounded by six convex peripheral figures, two on the anterior portion and a pair at both sides of the keel. In addition, four piliferous foramina lie on the posterior margin of the osteoderm, forming a single row.

Remarks. Species of Chasicotatus are primarily diagnosed by the external and internal morphology of the osteoderms (see Scillato-Yané et al., 2010). The described specimen of Chasicotatus represents the first record of the genus in La Rioja Province.

Family Glyptodontidae Gray, 1869

Subamily Hoplophorinae Huxley, 1864

Tribe Hoplophorini Huxley, 1864 HOPLOPHORINI INDET.

Figure 3.4-6

Referred material. CRILAR Pv 421: two osteoderms from the caudal rings and fragmentary osteoderms of the dorsal carapace (Fig. 3.4-6).

Procedence. Site 2 of El Degolladito area, La Rioja Province (Fig. 1.1, 2.2).

Description. The osteoderms from the caudal rings are rectangular in outline; the central figure is circular in outline and flat. The peripheral figures, located proximally and laterally to the central figure, are pentagonal to hexagonal in outline. Many foramina are developed on the articulation area of each osteoderm.

Remarks. Tauber (2005) mentioned the presence of Eosclerocalyptus planus (Rovereto, 1914) [= E. proximus (Moreno and Mercerat, 1891), according to Zurita (2007)] from the Salicas Formation, based on a scute of the posterior carapace region. However, Zurita (2007) considered this specimen too fragmentary for a specific identification. 
Order Notoungulata Roth, 1903

Suborder Typotheria Zittel, 1893

Family Hegetotheriddae Ameghino, 1894

Subamily Pachyrukhinae Kraglievich, 1934

Genus Paedotherium Burmeister, 1888

Type species. Paedotherium insigne Burmeister, 1888.

Paedotherium minor Cabrera, 1937 Figure 3.7-9

Referred material. CRILAR Pv 425: fragmentary right mandible with p3-m1 (Fig. 3.7); CRILAR Pv 426: fragmentary right mandible with $\mathrm{p} 4-\mathrm{m} 2$ (Fig. 3.8); and CRILAR Pv 427: fragmentary right mandible with p3-m3 (Fig. 3.9).

Procedence. Site 2 of El Degolladito area, La Rioja Province (Fig. 1.1, 2.2).

Description. The three specimens have similar features. The triangular trigonid of the premolars has a straighter and longer lingual face than the talonid. The molars of each specimen have a subtriangular trigonid with more convex sides than those of the talonid. The degree of cheek tooth imbrication is marked.

Remarks. The specimens described herein allow identification of Paedotherium minor based on anatomical features (e.g., degree of tooth imbrications are slightly greater than in P. bonaerense Ameghino, 1887, and P. typicum Ameghino, 1887) and size (i.e., smaller than P. bonaerense and P. typicum).

Family Mesotheriddae Alston, 1876

Subfamily Mesotherinae Alston, 1876

cf. Pseudotypotherium Ameghino, 1904

Figure 3.10

Referred material. CRILAR $\operatorname{Pv}$ 433: partial palate with both I1, the right tooth row (dP2?-M3), and fragments of the left M2 and M3, as well as the incomplete right zygomatic arch (Fig. 3.10).

Procedence. Site 1 of El Degolladito area, La Rioja Province (Fig. 1.1, 2.1).

Description. The two I1 are slightly anteriorly placed, kidney-shaped, and with a short but marked lingual groove. The outstanding feature of this specimen is the presence of three premolars. The first one (P2) is smaller than P3 and $\mathrm{P} 4$ and triangular. The $\mathrm{P} 3$ is subtriangular in outline, but with smoothly convex posterior and labial walls, and a hardly marked parastyle. $\mathrm{P} 4$ is a more molarized quadrangu- lar tooth, with a Y-shaped lingual groove, and the parastyle projecting over $\mathrm{P} 3$. The M1-M2 have a large middle lobe, reaching the lingual level of the anterior lobe, being the posterior lobe slightly more projected. In M3, the middle lobe is slightly shorter than the others and a little more triangular in outline. The parastyle projects over M2, and the metastyle directs backward forming a concave posterior face.

Remarks. The Subfamily Mesotheriinae is supposed to have an adult dental formula with only two upper premolars, P3-P4 (Francis, 1965; Pascual et al. 1966; Cerdeño and Montalvo, 2001). Therefore, the presence of three premolars in this specimen is a striking feature. It is not the only known mesotheriine with three premolars, but other specimens were previously recognized as carrying the deciduous dentition together with permanent molars (see Francis, 1960 and references therein). We consider that all premolars of CRILAR Pv 433 are the permanent ones and at least two interpretations are possible: it may correspond to a new taxon or it is a case of supernumerary tooth. Pending a detailed analysis, which is beyond the aim of this paper (Schmidt and Cerdeño in prep.), we determine the specimen as cf. Pseudotypotherium due to the presence of a lingual sulcus in the $\mathrm{P} 4$.

Order Litopterna Ameghino, 1889

Suborder Lopholipterna Cifelli, 1983

Family Proterotheriddae Ameghino, 1887

Subfamily Proterotherinae Ameghino, 1887

Genus Neobrachytherium Soria, 2001

Type species. Licaphrium intermedium Moreno and Mercerat, 1891.

\section{Neobrachytherium sp.}

Figure 3.11

Referred material. CRILAR Pv 429: right $\mathrm{P} 3-\mathrm{M} 1$ and left P3 (Fig. 3.11).

Procedence. Site 1 of El Degolladito area, La Rioja Province (Fig. 1.1, 2.1).

Description. Teeth with the anterolingual cingulum restricted to the anterior region, delimiting a fossettid. P3-P4 with protocone, paraconule, and metaconule joined in a continuous wearing surface. M1 squared in outline, showing a pronounced concavity between parastyle and mesostyle, and a groove between protocone and hypocone.

Remarks. P3-P4 of Neobrachytherium intermedium (Moreno and Mercerat, 1891) are more anteriorly rounded than in CRILAR Pv 429 and the metaconule extends to the meta- 
cone, whereas it is joined to the protocone and hypocone in CRILAR Pv 429. P4 differs from that of $N$. morenoi (Rovereto, 1914) in lacking a triangular denticulum at the base of the hypocone. The anterior cingulum of P3-M1 not projected lingually and the quadrangular outline of M1 resemble $N$. ameghinoi Soria, 2001. A specific determination is not reliable, but these remains represent the first record of Neobrachytherium for the Salicas Formation.

Order Rodentia Bowdich, 1821

Suborder Caviomorpha Wood, 1955

Family CaviIdae Fischer de Waldheim, 1817

Genus Orthomyctera Ameghino, 1889

Type species. Orthomyctera rigens Ameghino, 1889.

\section{Orthomyctera sp.}

Figure $\mathbf{3 . 1 2}$

Referred material. CRILAR Pv 423: left mandible with the p4-m3 series (Fig. 3.12)

Procedence. Site 2 of El Degolladito area, La Rioja Province (Fig. 1.1, 2.2).

Remarks. Specimen CRILAR Pv 423 is identified as $\mathrm{Or}$ thomyctera because of the following features: it is much smaller than living Dolichotis Desmarest, 1820, being similar in size to $O$. andina (Rovereto, 1914) and $O$. rigens Ameghino, 1889; the inferred total diastema length is not longer than the $\mathrm{p} 4-\mathrm{m} 3$ series length; and the $\mathrm{p} 4$ shows the anterior prism scarcely elongated anteriorly (see Ameghino, 1889; Kraglievich, 1932; Pascual et al., 1966; Ubilla and Rinderknecht, 2003). In reference to the p4, Pascual et al. (1966) pointed out that the anterior elongation of the anterior prism of the $\mathrm{p} 4$ is variable within Orthomyctera (less developed than in Dolichotis), being in certain cases just insinuate. The new material differs from $O$. andina, previously identified in the Salicas Formation (Tauber, 2005), by the following features: the $\mathrm{p} 4$ is relatively shorter in relation to the length of the molars (a feature similar to that of $O$. rigens Ameghino, 1889); the anterior prism of the p4 in CRILAR Pv 423 is less differentiated than in $O$. andina (see Rovereto, 1914, p. 59, fig. 25), a similar condition to that of $O$. rigens; and the horizontal crest (sensu Pérez, 2010) is more laterally extended at the level of $\mathrm{m} 1$. An important variability is recognized among the Miocene and Pliocene species included in Caviidae, so a taxonomic revision is needed for the group. In this context, we prefer to refer CRILAR Pv 423 to Orthomyctera sp.
Subfamily Cardiomyinae Kraglievich, 1940

\section{cf. Cardiomys Ameghino, 1885}

Figure 3.13

Referred material. CRILAR Pv 424: portion of right mandibular fragment with the $\mathrm{m} 2$ (Fig. 3.13).

Procedence. Site 2 of El Degolladito area, La Rioja Province (Fig. 1.1, 2.2).

Description. The molar has two heart-shaped prisms separated by a deep labial flexid (=hypoflexid). The posterior prism is anteroposteriorly longer than the anterior one. Each prism shows a lingual sulcus ("surco lobular interno"; Pascual et al., 1966). The lingual sulcus of the posterior prism is deeper than that of the anterior prism, which is not completely preserved. Enamel is thicker on the labial border of the prisms and reduced on the lingual surfaces.

Remarks. Specimen CRILAR Pv 424 is referred to cf. Cardiomys because it presents relatively superficial lingual sulci on both prisms of the tooth, i.e. a diagnostic condition for the genus (Pascual et al., 1966, p. 104-105). The specimen described herein is the first cardiomyine recorded from the Salicas Formation.

Family Chinchillidae Bennet, 1833

Subfamily Lagostominae Pocock, 1922

Genus Lagostomus Brookes, 1828

Subgenus Lagostomus (Lagostomopsis) Kraglievich, 1926

Type species. Lagostomus trichodactylus Brookes, 1828

\section{Lagostomus (Lagostomopsis) sp.}

\section{Figure 3.14}

Referred material. CRILAR Pv 430 right maxillary fragment with P4-M3 series (Fig. 3.14).

Procedence. Site 2 of El Degolladito area, La Rioja Province (Fig. 1.1, 2.2).

Remarks. The teeth of CRILAR Pv 430 are very similar in size and general shape to those of Lagostomus (Lagostomopsis) spp., having bilaminated $\mathrm{P} 4-\mathrm{M} 2$, and trilaminated M3 (with second and third laminae partially preserved). Note that, previously identified chinchillids from the Salicas Formation are known by lower dentition.

Superfamily Octodontoidea Waterhouse, 1839

Family Octodontidae Waterhouse, 1839

OCTODONTIDAE INDET.

Figure 3.15 
Referred material. CRILAR Pv 431: right mandibular fragment with dp4-m1 (Fig. 3.15).

Procedence. Site 2 of El Degolladito area, La Rioja Province (Fig. 1.1, 2.2).

Description. The masseteric crest begins behind the masseteric notch, without continuity between both structures. The masseteric notch is located somewhat above the middle mandibular height and at the level of dp4 and anterior portion of $\mathrm{m} 1$. The preserved portion of the incisor shows that this tooth is high and narrow. The deciduous tooth (dp4) is somewhat longer than $\mathrm{m} 1$, showing a tetralophodont pattern, with well developed metalophulid I, mesolophid, hypolophid, and posterolophid. In addition, a small crest (metalophulid II? sensu Candela, 2002) is connected to metalophulid I, and posterolabially oriented towards the center of the anterofossettid, which is sub-circular in shape. The mesolophid is anterolingually oriented. The metaflexid is shallower than the mesoflexid, indicating that the latter is more persistent, and both flexids are shallower than the hypoflexid. In labial view, this flexid extends to about $2 / 3$ of the emerged crown. Molar $\mathrm{m} 1$ is protohypsodont, somewhat longer than wide, and trilophodont, without indication of metalophulid II (sensu Candela, 2002). The mesoflexid is projected towards the anterior border of the molar. This flexid is deeper than the metaflexid (a feature clearly seen in lingual view), indicating that the latter closes before the former. Both flexids are less persistent than the hypoflexid.

Remarks. Specimen CRILAR Pv 431 is assigned to Octodontidae by the following features: the masseteric crest is posterior to the masseteric notch, so this crest does not include the masseteric notch (Verzi, 1999), and the metaflexid closes before the mesoflexid (Verzi et al., 1999), whereas in octodontoids Echimyidae, the metaflexid is more persistent than the mesoflexid. Preliminary observations indicate similarities and differences between CRILAR Pv 431 and the octodontids Neophanomys biplicatus Rovereto, 1914, previously recognized in the Salicas Formation (Tauber, 2005), Chasichimys Pascual, 1967, and certain specimens of Acarechimys Patterson, 1965 (in Kraglievich, 1965). CRILAR Pv 431 shares with Neophanomys the following diagnostic features of the genus (see Verzi et al., 1999: 84): incisor high and narrow, lingual flexids less persistent than the hypoflexid; tetralophodont $\mathrm{dp} 4$, and trilophodont and protohypsodont molars. CRILAR Pv 431 differs from specimens of $N$. biplicatus by its larger size, the relatively less simultaneous closure of the lingual flexid (metaflexid close before mesoflexid), the presence of a small crest within anterofossettid in $\mathrm{dp} 4$, and the absence the vestige of metalophulid II in $\mathrm{m} 1$, which is present at least in some specimens of $N$. biplicatus (see Verzi et al., 1999). Compared with youngest specimens of Chasichimys bonaerense Pascual, 1967 (see Verzi, 1999: fig. 2), the dp4 of CRILAR Pv 431 shows more persistent flexids and lophids. On the other hand, the $\mathrm{m} 1$ of CRILAR Pv 431 is comparable in size to that of Chasichimys bonaerense (see Verzi, 1999: table 1) and, as in Chasichimys spp., the $\mathrm{m} 1$ of CRILAR Pv 431 is protohypsodont, trilophodont, with the mesoflexid projected towards the anterior border of the molar, and the hypoflexid more persistent than the

$\overline{\overline{T A B L E} \text { 1. Mammal genera shared among the Salicas Formation and other Miocene-Pliocene units/géneros de mamíferos compartidos entre la }}$ Formación Salicas y otras unidades del Mioceno-Plioceno

\begin{tabular}{|c|c|c|c|c|c|c|c|}
\hline & $\begin{array}{c}\text { Salicas } \\
\text { Fm. }\end{array}$ & $\begin{array}{l}\text { Chiquimil Fm. } \\
\text { El Jarillal Mb. }\end{array}$ & $\begin{array}{c}\text { Andalhuala } \\
\text { Fm. }\end{array}$ & $\begin{array}{c}\text { Corral Quemado } \\
\text { Fm. }\end{array}$ & $\begin{array}{c}\text { Río Quinto } \\
\text { Fm. }\end{array}$ & $\begin{array}{c}\text { Cerro Azul } \\
\text { Fm. }\end{array}$ & $\begin{array}{c}\text { Arroyo Cha- } \\
\text { sicó Fm. }\end{array}$ \\
\hline Macrochorobates & $x$ & $x$ & $x$ & & $x$ & $x$ & \\
\hline Proeuphractus & $x$ & $x$ & & & & $x$ & \\
\hline Chaetophractus & $x$ & & & & & & \\
\hline Eosclerocalyptus & $x$ & $x$ & $x$ & & & $x$ & \\
\hline Paedotherium & $x$ & $?$ & & & $x$ & $x$ & $x$ \\
\hline Tremacyllus & $?$ & $x$ & $x$ & & $x$ & & \\
\hline Hemihegetotherium & $x$ & & $x$ & $x$ & & $x$ & \\
\hline Pseudotypotherium & $x$ & & & & & $x$ & \\
\hline Protypotherium & $x$ & & & & & & \\
\hline Neobrachytherium & $x$ & & $x$ & $x$ & & & $x$ \\
\hline Cardiomys & $?$ & $x$ & $x$ & & & $x$ & \\
\hline Lagostomus (Lagostomopsis) & $x$ & $x$ & $x$ & & $x$ & $x$ & $x$ \\
\hline Neophanomys & $x$ & $x$ & $x$ & & & $x$ & \\
\hline Potamarchus & $x$ & $x$ & & & & $x$ & \\
\hline
\end{tabular}


lingual flexids. CRILAR Pv 431 shares with some specimens of Acarechimys coming from Colloncuran (Middle Miocene; Neuquén Province; Vucetich et al., 1993) a small crest crossing the subcircular anterofossetid in dp4, but differs by having higher tooth crown, and the absence of remnant of second lophid (metalophulid II?), which is frequent in specimens of Acarechimys (in Acarechimys spp. this lophid is variable in development, being in $A$. constans, at least in the $\mathrm{m} 1$ of holotype of this species, more developed). In this context, it is possible to suggest that the CRILAR Pv 431 represents a new Octodontidae. However, differences and similarities between CRILAR Pv 431 and Neophanomys biplicatus, Chasichimys, and certain specimens of Acarechimys requires further evaluation.

\section{DISCUSSION}

\section{Diversity}

The diversity of mammals from the Salicas Formation previously recognized included twelve genera (Tauber, 2005). This contribution increases the knowledge about the mammalian fossil record by adding the first reports of Chasicotatus, Paedotherium, Neobrachytherium, cf. Cardiomys (Tab. 1), and probably two new taxa. The latter are represented by the palate assigned to cf. Pseudotypotherium and the mandibular fragment referred to Octodontidae.

Regarding Chasicotatus, four species are known from Argentina: (1) Ch. ameghinoi Scillato-Yané, 1979, typical of the Arroyo Chasicó Formation (Buenos Aires Province), the Cerro Azul Formation (La Pampa Province), and the Jarillal Member of the Chiquimil Formation (Catamarca Province) (see Esteban and Nasif, 1999; Urrutia et al., 2008; Scillato-Yané et al., 2010); (2) Ch. peiranoi Esteban and Nasif, 1996 from the late Miocene of Buenos Aires Province and Andalhuala Formation,Catamarca Province (ScillatoYané et al., 2010); (3) Ch. powelli Scillato-Yané, Krmpotic, and Esteban, 2010 from the late Miocene of the Valle del Cajón, Catamarca Province (Scillato-Yané et al., 2010); and (4) Ch. spinozai Scillato-Yané, Krmpotic, and Esteban 2010 from the "conglomerado osífero" at the base of the Ituzaingó
Formation (Entre Ríos Province; Scillato-Yané et al., 2010). These records, and the material here reported from the Salicas Formation, suggest that Chasicotatus was broadly distributed during the late Miocene of Argentina (Scillato-Yané et al., 2010). In addition to the scutes of Chasicotatus, Macrochorobates, and Hoplophorini described herein, several other isolated scutes that belong to different genera of Xenarthra Cingulata were recorded from the Salicas Formation, including Proeuphractus limpidus Ameghino, 1886, Proeuphractus sp., Chaetophractus sp., and Eosclerocalyptus sp. (see Tauber, 2005; Zurita, 2007).

In Argentina, Paedotherium minor has been recorded from the Arroyo Chasicó and Cerro Azul formations and probably from El Jarillal Member of the Chiquimil Formation (see Cerdeño and Bond, 1998). The genus was also identified in the Río Quinto Formation (San Luis Province; Prado et al., 1998). The record reported herein is the first definite record of Pachyrukhinae other than Tremacyllus from the Salicas Formation.

Regarding Mesotheriinae, specimens coming from the Salicas Formation were previously assigned to Pseudotypotherium sp. (Tauber, 2005). Although the palatal fragment studied herein is referred preliminarily to cf. Pseudotypotherium, it presents some peculiarities in the dentition that might correspond to a new taxon. In addition to these Notoungulata, the hegetotheriid Hemihegetotherium cf. torresi (Cabrera and Kraglievich, 1931) and the interatherid Protypotherium sp. were also mentioned for the Salicas Formation (Tauber, 2005).

Neobrachytherium is known by four species: (1) N. intermedium (=Licaphrium intermedium Moreno and Mercerat, 1891) from the Corral Quemado Formation, Catamarca Province; (2) N. morenoi, also from the Corral Quemado Formation; (3) N. ameghinoi, from the "conglomerado osífero"; and (4) N. ullumense Soria, 2001, from the Loma de las Tapias Formation (San Juan Province) and the Arroyo Chasicó Formation (see Soria, 2001; Cerdeño, 2003). Its recognition in the Salicas Formation is, therefore, not surprising, due to the probable late Miocene age of this locality, and increases the geographical distribution of this species in Western Argentina.

Figure 3. Mammals from the Salicas Formation/ mamíferos de la Formación Salicas. 1-2, Macrochorobates (CRILAR Pv 420), 1, fixed osteoderm/ osteodermo fijo; 2, moveable osteoderm/ osteodermo móvil. 3, Chasicotatus (CRILAR Pv 428), fixed osteoderm/ osteodermo fijo. 4-6, Hoplophorini indet. (CRILAR Pv 421), osteoderms/ osteodermos. 7, Paedotherium minor (CRILAR Pv 425), fragmentary right mandible with $\mathrm{p} 3-\mathrm{m} 1 /$ fragmento de mandíbula derecha con $p 3-m 1.8$, Paedotherium minor (CRILAR Pv 426), fragmentary right mandible with p4-m2/ fragmento de mandíbula derecha con $p 4-m 2$. 9, Paedotherium minor (CRILAR Pv 427), fragmentary right mandible with $\mathrm{p} 3-\mathrm{m} 3 /$ fragmento de mandibula derecha con $\mathrm{p} 3-\mathrm{m} 3$. 10, cf. Pseudotypotherium (CRILAR Pv 433), partial palate/ paladar parcial. 11, Neobrachytherium sp. (CRILAR Pv 429), right P3-M1 and left P3/ P3-M1 derechos y P3 izquierdo. 12, Orthomyctera sp. (CRILAR Pv 423), left mandible with the $\mathrm{p} 4-\mathrm{m} 3$ series/ mandibula izquierda con $p 4-m 3$. 13, cf. Cardiomys (CRILAR Pv 424), right mandibular fragment with the $\mathrm{m} 2 /$ fragmento de mandibula derecha con m2. 14, Lagostomus (Lagostomopsis) sp. (CRILAR Pv 430), right maxillary fragment with P4-M3 series/ fragmento de maxilar derecho con P4-M3. 15, Octodontidae indet. (CRILAR PV 431), right mandibular fragment with dp4-m1/fragmento mandibular derecho con dp4-m1. A, anterior. M, mesial. Scale bar, $10 \mathrm{~mm} / \mathrm{Escala}, 10 \mathrm{~mm}$. 


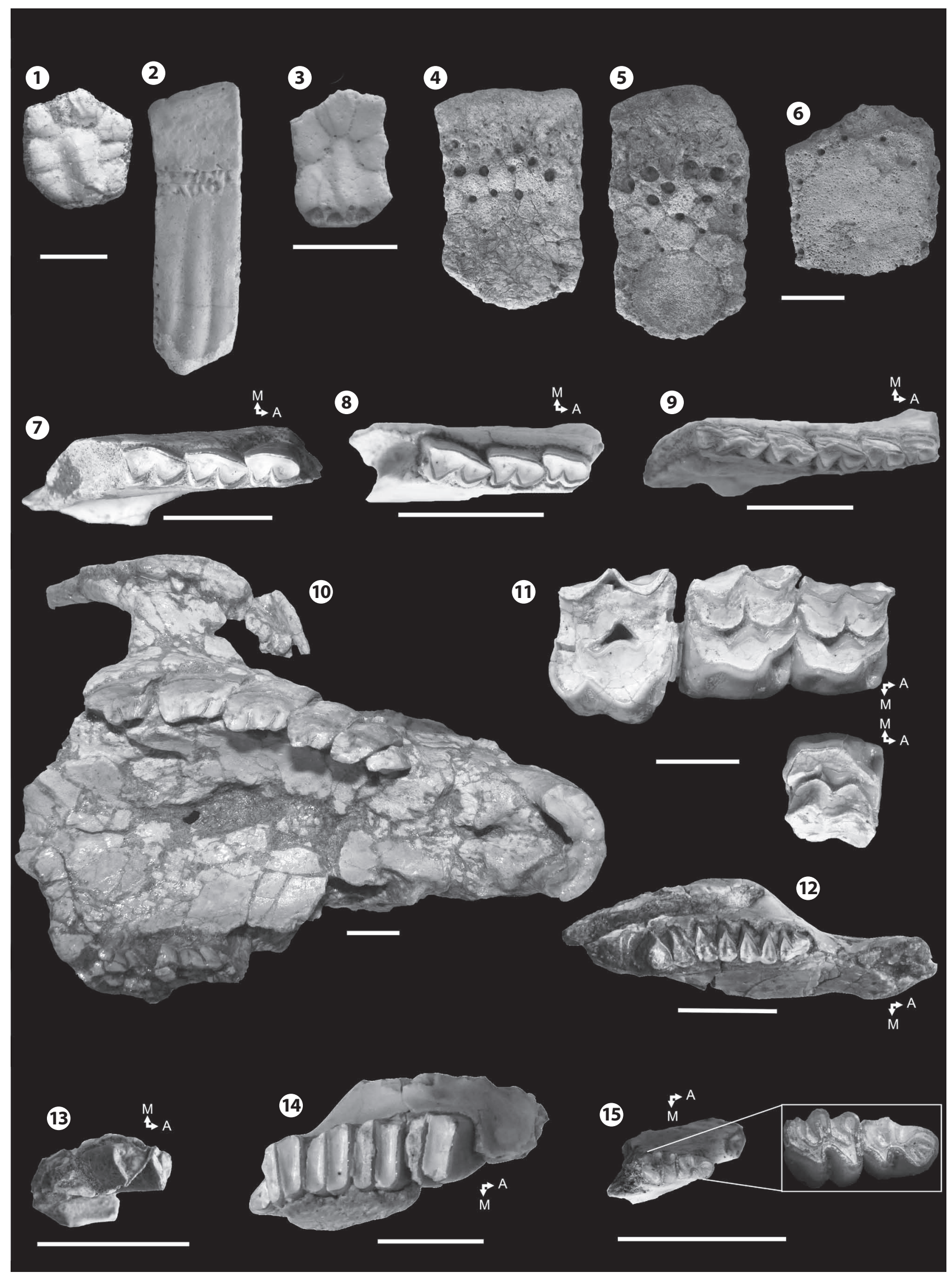


The extinct Cardiomyinae are recognized since the late Miocene of Argentina. In addition to the record reported herein, Cardiomys was recorded in the Cerro Azul, Las Arcas (Catamarca Province), Ituzaingó, and Chapadmalal (Buenos Aires Province) formations (Nasif et al., 1997; Goin et al., 2000; Cione et al., 2000; Vizcaíno et al., 2004).

Octodontidae possibly related to CRILAR Pv 431 are well represented in different late Miocene units of Argentina. Neophanomys biplicatus Rovereto, 1914, was reported from the Andalhuala and Chiquimil formations (Catamarca Province), Huayquerías and Tunuyán formations (Mendoza Province), Cerro Azul Formation (Verzi et al., 1999, Nasif and Esteban, 2000, Montalvo et al., 2009), and Salicas Formation (Tauber, 2005). In addition to these rodents, Orthomyctera andina and probably another species of this genus, Lagostomus (Lagostomopsis) cf. pretrichodactyla (Rovereto, 1914), and Potamarchus sp. were recorded in the Salicas Formation (Tauber, 2005).

\section{PALEOBIOGEOGRAPHY AND AGE OF THE SALICAS FORMATION}

Most of the specimens analyzed herein could not be identified at the specific level mainly because of their fragmentary state of preservation. However, generic identifications may possibly help to establish chronological and biogeographical relationships among the Salicas Formation mammal association and those coming from other late Miocene-Pliocene units of Argentina (see Marshall and Patterson, 1981; Prado et al., 1998; Cerdeño and Bond, 1998; Goin et al., 2000; Esteban et al., 2001; Cione and Tonni, 2005; Rodríguez Brizuela and Tauber, 2006; Zurita, 2007; Reguero et al., 2007; Urrutia et al., 2008; Verzi et al., 2008; Montalvo et al., 2009; Scillato-Yané et al., 2010, among others).

Considering the presence of mammal genera (including dubious records), the Salicas Formation shares twelve genera with the Cerro Azul Formation, eleven with the El Jarillal Member of Chiquimil Formation, nine with the Andalhuala Formation, four with the Río Quinto Formation, four with the Arroyo Chasicó Formation, and two with the Corral Quemado Formation (Tab. 1). Among those associations, the Salicas Formation fauna shares more taxa with that from Central Argentina (i.e., La Pampa Province). Among those coming from Northwestern Argentina, its major affinity is with the El Jarillal Member (Chiquimil Formation) and then the Andalhuala Formation (both in Catamarca Province) (see Marshall and Patterson, 1981; Tauber, 2005; Reguero and Candela, 2011).
The calibration of the stages/ages scheme for the late Neogene of South America is controversial. The boundaries between the Chasicoan and the Huayquerian, and the Huayquerian and the Monterhermosan remain unresolved as there is no agreement among researchers. Traditionally, the base of the Huayquerian (i.e., the Chasicoan/Huayquerian boundary) was located at about $9 \mathrm{Ma}$ and its top at 6.8 Ma (Flynn and Swisher, 1995; Cione et al., 2000; Reguero and Candela, 2011). Recently, the Huayquerian/Montehermosan boundary was located at about $5.3 \mathrm{Ma}$ (Verzi and Montalvo, 2008; Verzi et al., 2008).

An accurate age for the Salicas Formation is not easily deduced given the absence of radiometric datings for the unit. Tauber (2005, p. 456) suggested a Huayquerian age for the Salicas assemblage, considering a Montehermosan age less probable. As was mentioned, the Salicas Formation shares many genera with the geographically closely exposed Chiquimil and Andalhuala formations, for which radiometric ages are available. A dating of the base of the El Jarillal Member (Chiquimil Formation, at level 8, in the Puerta de Corral Quemado area, according to Marshall and Patterson, 1981) provided an age of $6.68 \mathrm{Ma}$; whereas the Andalhuala Formation (at level XIX, in Chiquimil area, according to Marshall and Patterson, 1981) provided and age of 6.02 Ma (see Marshall and Patterson, 1981; Reguero and Candela, 2011). As was detailed above, this range corresponds either to the Huayquerian or the Montehermosan depending on which authors are followed.

For the base of the Montehermosan, Reguero and Candela (2011) defined the Biozone of Cyonasua brevirostris (Moreno and Mercerat, 1891) for Northwestern Argentina on the basis of the Andalhuala Formation mammal assemblage (see Reguero and Candela, 2011). Until now, Cyonasua brevirostris has not been recorded in the Salicas Formation, but other taxa with broader chronological distribution (e.g., Tremacyllus, Orthomyctera are also present in this biozone. On the other hand, Macrochorobates scalabrinii is used to define a local biozone in Buenos Aires Province which is referred to the Huayquerian (Cione and Tonni, 2005) and it is present in the Salicas Formation.

In summary, we consider the Salicas Formation fauna as latest Miocene in age until new fossil discoveries and radioisotopic dates allow a better calibration.

\section{PALEOENVIRONMENT}

The current understanding of the biota in the Salicas Formation does not allow a complete paleoenvironmental 
interpretation. Recent contributions worked with a scattered record of fossil mammals (Tauber, 2005) and with paleobotanical evidence of the presence of Leguminosae Mimosoideae (Pujana, 2010). The xenarthran cingulate community suggests the predominance of open environments in warm conditions (see Zurita, 2007; Scillato-Yané et al., 2010). In addition, dry environmental conditions were proposed for the habitat of Paedotherium (Kraglievich, 1926; Zetti, 1972; Bondesio et al., 1980). Mesotheriids were formerly compared ecomorphologically to the extant giant semi-aquatic capybara rodents (Bond et al., 1995). However, Shockey et al. (2007) recently indicated some fossorial or semi-fossorial adaptations for them. Morphological variation within proterotheriids — mainly reflected in different hypsodonty degree and size - suggests different habitats, from closed and forested areas to open environments (Villafańe et al., 2006). With few exceptions (Candela, 2004; Candela and Picasso, 2008), late Miocene caviomorphs have not been analyzed from a morphofunctional adaptive perspective, making it difficult to infer their palaeonvironmental significances. However, if the metabolic and ecological requirements of chinchillids from the Salicas Formation were comparable to those of the related living forms; then, they would probably had preferred relatively open areas, such as most current species of those groups do. In addition to the mammal community, Tauber (2005) recorded turtles, birds (probably Ciconiidae), anurans, gastropods, and aquatic plants. $\mathrm{He}$ also interpreted the facies association as channel deposits and alluvial plains suffering oscillating flooding and drought periods. The caliche soils indicate periods of semiarid climate, whereas alternative Bt levels (argillaceous) would represent a more humid climate or more stable hydrological conditions, for example inside inter-channel areas. The differences in average grain-size between the Salicas and Las Cumbres formations would evidence the passage from a lower energy environment to a more dynamic regimen. This would be related to a tectonic inversion episode during the Plio-Pleistocene (Bossi et al., 2009). These authors inferred that the Salicas Formation was associated to an environment of plains with source areas characterized by a lower and smooth relief, representing a stage previous to uplift of the Velasco range.

The information provided by the fossil biota and the geological interpretation suggest that the Salicas Formation could be deposited in flatlands under average warm and dry conditions. This environment was probably dominated by open grassland with forested areas near rivers and lagoons, being exposed to episodic flooding typical of semi-desertic environ- ments. Levels of argillaceous palaeosols, evidenced mainly at the lower portion of the stratigraphic sequence, would be indicative of alternative periods of climatic improvement.

\section{ACKNOWLEDGMENTS}

Discussions with G.J. Scillato-Yané, C.M. Krmpotic, M.R.Ciancio, L.R. González Ruíz, A.E. Zurita, E. Cerdeño, L. Rasia, and M.E. Pérez improved this contribution. N. Nasif, C. Montalvo, and an anonymous reviewer improved this contribution by providing constructive critical revisions. M. Griffin and A. Forasiepi provided helpful suggestions; R.I. Vezzosi helps in the fieldwork, and A. Isaacson improved the English. We also thank the Consejo Nacional de Investigaciones Científicas y Tecnológicas (CONICET). This paper is a contribution to the following projects: PICT 2007392 and PIP 886.

\section{REFERENCES}

Alston, E.R. 1876. On the classification of the order Glires. Proceedings of the Zoological Society of London 1876: 61-98.

Ameghino, C. 1919. Sobre mamíferos fósiles del Piso Araucanense de Catamarca y Tucumán. $1^{a}$ Reunión Nacional de la Sociedad Argentina de Ciencias Naturales (Tucumán, 1916), Actas: 151-152.

Ameghino, F. 1885. Nuevos restos de mamíferos fósiles Oligocenos recogidos por el Profesor Pedro Scalabrini y pertenecientes al Museo Provincial de la ciudad de Paraná. Boletín de la Academia Nacional de Ciencias de Córdoba 8: 5-207.

Ameghino, F. 1886. Contribuciones al conocimiento de los mamíferos fósiles de los terrenos terciarios antiguos del Paraná. Boletín de la Academia Nacional de Ciencias de Córdoba 9: 5-228.

Ameghino, F. 1887. Apuntes preliminares sobre algunos mamíferos extinguidos del yacimiento de Monte Hermoso. Obras completas y correspondencia cientifica 5: 339-353.

Ameghino, F. 1889. Contribución al conocimiento de los mamíferos fósiles de la República Argentina. Actas de la Academia Nacional de Ciencias de Córdoba 6: 1-1027.

Ameghino, F. 1891. Mamíferos y aves fósiles argentinos: especies nuevas. Adiciones y correcciones. Revista Argentina de Historia Natural 1: 240-259.

Ameghino, F. 1894. Enumération synoptique des espèces mammiferes fossiles des formations éocènes de Patagonie. Boletín de la Academia Nacional de Ciencias de Córdoba 13: 259-452.

Ameghino, F. 1904. Nuevas especies de mamíferos cretáceos y terciarios de la República Argentina. Anales de la Sociedad Cientifica Argentina de Buenos Aires 57: 162-175.

Bennett, E.T. 1833. On the family of Chinchillidae, and on a new genus referable to it. Proceeding Zoology Society of London 1883: 57-60.

Bond, M., Cerdeño, E. and López, G. 1995. Los ungulados nativos de América del Sur. In: M.T. Alberdi, G. Leone and E.P. Tonni (Eds.), Evolución Biológica y Climática de la Región Pampeana durante los últimos Cinco Millones de años. Monografías del Museo de Ciencias Naturales de Madrid 12, p. 257-276Bondesio, P., Laza, J.H., Scillato-Yané, G. J., Tonni, E.P. and Vucetich, M.G. 1980. Estado actual del conocimiento de los vertebrados de la Formación Arroyo Chasicó (Plioceno temprano) de la provincia de Buenos Aires. $2^{d o}$ Congreso Argentino de Paleontología $y$ Bioestratigrafia y $1^{\text {er }}$ Congreso Latinoamericano de Paleontología, (Buenos Aires, 1978), Actas 3: 101-127.

Bordas, A.F. 1933. Notas sobre los Eutatinae. Nueva subfamilia extinguida de Dasypodidae. Anales del Museo Nacional de Historia Natural 37: 583-614.

Bossi, G.E., Georgieff, S.M. and Vides, M.E. 2007. Arquitectura y paleoambientes de los depósitos fluviales gravosos de la Formación Las Cum- 
bres (Neógeno), en Villa Mervil, La Rioja, Argentina. Latin American Journal of Sedimentology and Basin Analysis 14: 53-75.

Bossi, G.E., Georgieff, S.M., Gravriloff, I.J.C., Ibáńez, L.M. and Muruaga, C.M. 2001. Cenozoic evolution of the intermontane Santa María Basin, Pampean Ranges, northwestern Argentina. Journal of South America Earth Sciences 14: 725-734.

Bossi, G.E., Georgieff, S.M., Muruaga, C., Ibáñez, L.M. and Sanagua, J.G 2009. Los conglomerados sintectónicos de la Formación Las Cumbres (Plio-Pleistoceno), Sierras Pampeanas de La Rioja y Catamarca, Argentina. Andean Geology 36: 172-196.

Brookes, J. 1828. A new genus of the order Rodentia. Transactions of the Linnean Society 16: 96-105.

Burmeister, C.V. 1888. Relación de un viaje a la Gobernación de Chubut. Anales del Museo Nacional de Buenos Aires 3: 175-252.

Burmeister, G. 1885. Examen crítico de los mamíferos y los reptiles denominados por Don Augusto Bravard. Anales del Museo Público de Buenos Aires 3: 95-173.

Cabrera, A. 1937. Notas sobre el Suborden Typotheria. Notas Museo de La Plata, Paleontología 2: 17-43.

Cabrera, A. and Kraglievich, L. 1931. Diagnosis previas de los ungulados fósiles del Arroyo Chasicó. Notas preliminares del Museo de La Plata 1: $107-113$.

Candela, A.M. 2002. Lower deciduous tooth holomologies in Erethizontidae (Rodentia, Hystricognathi): evolutionary significance. Acta Paleontologica Polonica 47: 117-723.

Candela, A.M. 2004. A new giant porcupine (Rodentia, Erethizontidae) from the late Miocene of northwestern Argentina. Journal of Vertebrate Paleontology 24: 732-741.

Candela, A.M. and Picasso, M. 2008. Functional anatomy of the limbs of Erethizontidae (Rodentia, Caviomorpha): indicators of locomotor behavior in Miocene porcupines. Journal of Morphology 269: 552-593.

Cerdeño, E. 2003. Neobrachytherium ullumense (Proterotheriidae, Litopterna) en el Mioceno Superior de la Provincia de Buenos Aires (Argentina). Ameghiniana 40: 505-508.

Cerdeño, E. and Bond, M. 1998. Taxonomic revision and phylogeny of Paedotherium and Tremacyllus (Pachyrukhinae, Hegetotheriidae, Notoungulata) from the late Miocene to the Pleistocene of Argentina. Journal of Vertebrate Paleontology 18: 799-811.

Cerdeńo, E. and Montalvo, C.I. 2001. Los Mesotheriinae (Mesotheriidae, Notoungulata) del Mioceno Superior de La Pampa, Argentina. Revista Española de Paleontología 16: 63-75.

Cione, A.L. and Tonni, E.P. 1999. Biostratigraphy and chronological scale of upper-most Cenozoic in the Pampean Area, Argentina. In: A.L. Cione and E.P. Tonni (Eds.), Quaternary Vertebrate Paleontology in South America, Quaternary of South America and Antarctic Peninsula, Special Volume 12, p. 23-51.

Cione, A.L. and Tonni, E.P. 2005. Bioestratigrafía basada en mamíferos del Cenozoico Superior de la provincia de Buenos Aires, Argentina. In: R.E.de Barrio, R.O. Etcheverry, M.F. Caballé, and E. Llambías (Eds.), Geología y Recursos Minerales de la Provincia de Buenos Aires. $16^{\text {to }}$ Congreso Geológico Argentino 11, (La Plata, 2005), Relatorio 11: 183-200.

Cione, A.L., Azpelicueta, M.M., Bond, M., Carlini, A.A., Casciotta, J., Cozzuol, M., De La Fuente, M., Gasparini, Z., Goin, F.J., Noriega, J.I., Scillato-Yané, G.J., Soibelzon, L., Tonni, E.P., Verzi, D.H. and Vucetich, M.G. 2000. Miocene vertebrates from Paraná, Eastern Argentina. INSUGEO, Serie Correlación Geológica 14: 191-237.

Desmarest, A.G. 1820. Mammalogie ou description des espèces de mammiferes. Pt. 1 contenant les ordres des Bimanes, des Quadrumanes et des Carnassiers. Mme. Veuve Agasse, Paris, 276 p.

Esteban, G. and Nasif, N. 1996. Nuevos Dasypodidae (Mammalia, Xenarthra) del Mioceno tardío del Valle del Cajón, Catamarca, Argentina. Ameghiniana 33: 327-334.

Esteban, G.I. and Nasif, N.L. 1999. Mamíferos fósiles de la formación
Chiquimil (Mioceno tardío), provincia de Catamarca, Argentina. Bioestratigrafía. Ameghiniana, Suplemento Resúmenes 36: R11.

Esteban, G., Nasif, N. and Montalvo, C. 2001. Nuevos registros de Dasypodiadae (Xenarthra) del Mioceno tardío de la provincia de La Pampa (Argentina). Revista Española de Paleontología 16: 77-87.

Fischer de Waldheim, G. 1817. Adversaria zoologica. Mémoires de la Société Impériale des Naturalistes de Moscou 5: 357-428.

Fitzinger, L.J. 1871. Die natürliche Familie der Gürteltiere (Dasypodes). Sitzungsberichte Mathematisch-Naturwissenschaftliche Klasse der Akademie der Wissenschaften, Wien 64: 209-276, 329-390.

Flynn, J.J. and Swisher, C.C. 1995. Cenozoic South American Land-mammal ages: correlation to global geochronologies. In: W.A. Berggren, D.V. Kent, M. Aubry and J. Handerbol (Eds.), Geochronology, Time scales, and Correlation: Framework for a Historical Geology. SEPM Special Publication 54, p. 317-333.

Francis, J.C. 1960. Análisis de algunos factores de confusión en la sistemática genérica de los Mesotheriinae (Notoungulata, Typotheria). Ameghiniana 2: 29-36.

Francis, J.C. 1965. Los géneros de la subfamilia Mesotheriinae (Typotheria, Notoungulata) de la República Argentina. Boletín del Laboratorio de Paleontología de Vertebrados 1: 7-23.

Georgieff, S., Herbst, R., Esteban, G. and Nasif, N. 2004. Análisis paleoambiental y registro paleontólogico de la Formación Desencuentro (Mioceno superior), Alto de San Nicolás, La Rioja, Argentina. Ameghiniana 41: 45-56.

Goin, F., Montalvo, C. and Visconti, G. 2000. Los marsupiales (Mammalia) del Mioceno superior de la Formación Cerro Azul (provincia de La Pampa, Argentina). Estudios Geológicos 56: 101-126.

Gray, J.E. 1821. On the natural arrangement of vertebrose animal. London Medical Repository 15: 296-310.

Gray, J.E. 1869. Catalogue of carnivorous, pachydermatous and edentate Mammalia in the British Museum. British Museum (Natural History) Publications, London, 398 p.

Huxley, T.H. 1864. On the osteology of the genus Glyptodon. Proceedings of the Royal Society of London 13: 1-108.

Kraglievich, J.L. 1965. Speciation phylétique dans les rongeurs fossiles du genre Eumysops Amegh. (Echimyidae, Heteropsomyinae). Mammalia 29: $258-267$.

Kraglievich, L. 1926. Sobre el conducto humeral de las vizcachas y paquirucos chapadmalalenses con descripción del Paedotherium imperforatum. Anales del Museo de Historia Natural "Bernardino Rivadavia”34: 45-88.

Kraglievich, L. 1932. Diagnosis de nuevos géneros y especies de roedores cávidos y eumegámidos fósiles de la Argentina. Rectificación genérica de algunas especies conocidas, y adiciones al conocimiento de otras. Anales de la Sociedad Cientifica Argentina 115: 155-181, 211-237.

Kraglievich, L. 1934. La antigüedad pliocena de las faunas de Monte Hermoso y Chapadmalal, deducidas de su comparación con las que le precedieron y sucedieron. Imprenta El Siglo Ilustrado, Montevideo, 136 p.

Kraglievich, L. 1940. Descripción detallada de diversos roedores argentinos terciarios clasificados por el autor. In: A.J. Torcelli (Ed), Obras completas y trabajos cientificos inéditos de Lucas Kraglievich. Obras de Geología y Paleontología 2: 297-330.

Krapovickas, V. and Nasif, N. 2010. Huellas de dinómidos (Dinomyidae, Hystricognathi) en el Oligoceno tardío de la provincia de La Rioja, Argentina. $10^{\text {mo }}$ Congreso Argentino de Paleontología y Bioestratigrafia y $7^{\text {mo }}$ Congreso Latinoamericano de Paleontología (La Plata, 2010), resúmenes: 83-84.

Krapovickas, V., Ciccioli, P.L., Mángano, M.G., Marsicano, C.A. and Limarino, C.O. 2009. Paleobiology and paleoecology of an arid-semiarid Miocene South American ichnofauna in anastomosed fluvial deposits. Palaeogeography, Palaeoclimatology, Palaeoecology 284: 129-152.

Marshall, L.G. and Patterson, B. 1981. Geology and geochronology of the mammal-bearing Tertiary of the valle de Santa María and río Corral Quemado, Catamarca province, Argentina. Fieldiana, geology 9: 1-80. 
Marshall, L.G., Berta, A., Hoffstetter, R., Pascual, R., Bombin, M. and Mones, A. 1984. Mammals and Stratigraphy: geochronology of the continental mammal-bearing Quaternary of South America. Paleovertebrata, Mémoire Extraordinaire, 76 p.

Miall, A.D. 1990. Principles of sedimentary basin analysis. $2^{\text {nd }}$ Edition, Springer-Verlag Inc., New York, 668 p.

Montalvo, C.I., Verzi, D.H., Tallade, P.O. and Zárate, M.A. 2009. Nueva asociación faunística del Huayqueriense (Mioceno tardío) del este de La Pampa, Argentina. Ameghiniana, Suplemento Resúmenes 46: 38R.

Moreno, F.P. and Mercerat, A. 1891. Exploración arqueológica de la Provincia de Catamarca: paleontología. Revista del Museo de La Plata 1: 222-236.

Nasif, N. and Esteban, G., 2000. Nuevo registro de Neophanomys biplicatus (Octodontidae, Caviomorpha) en el Terciario tardío del Noroeste argentino. Ameghiniana, Suplemento Resúmenes 37: 13R.

Nasif, N., Esteban, G., Musalem, S. and Herbst, R. 1997. Primer registro de vertebrados fósiles para la Formación Las Arcas (Mioceno tardío), Valle de Santa María, provincia de Catamarca, Argentina. Ameghiniana, Suplemento Resúmenes 34: 538R.

Pascual, R. 1967. Los roedores Octodontoidea Caviomorpha) de la Formación Arroyo Chasicó (Plioceno inferior) de la Provincia de Buenos Aires. Revista del Museo de La Plata 5: 259-282.

Pascual, R., Ortega-Hinojosa, E.J., Gondar, D.G. and Tonni, E.P. 1966. Vertebrata. In: A.V. Borrello (Ed.), Paleontografía Bonaerense. Comisión de Investigaciones Científicas de la provincia de Buenos Aires, 202 p.

Pérez, M.E. 2010. [Sistemática, ecología y bioestratigrafía de Eocardiidae (Rodentia, Hystricognathi, Cavioidea) del Mioceno temprano y medio de Patagonia. Doctoral Thesis, Universidad Nacional de La Plata, 357 p. Unpublished].

Pocock, R.I. 1922. On the external characters of hystricomorph rodents. Proceedings of the Zoological Society of London 92: 365-427.

Pocock, R.I. 1924. The external characters of the South American Edentates. Proceedings of the Zoological Society of London 94: 983-1031.

Prado, J., Chiesa, J., Tognelli, G., Cerdeño, E.,and Strasser, E. 1998. Los mamíferos de la Formación Río Quinto (Plioceno), Provincia de San Luis, Argentina. Aspectos bioestratigráficos, zoogeográficos y paleoambientales. Estudios Geológicos 54: 153-160.

Pujana, R.R. 2010. Una nueva Mimosoideae (Leguminosae) de la Formación Salicas (Mioceno), provincia de La Rioja, Argentina. $10^{\text {mo }}$ Congreso Argentino de Paleontología y Bioestratigrafia y $7^{m o}$ Congreso Latinoamericano de Paleontología (La Plata, 2010), resúmenes: 203.

Reguero, M., Candela, A.M. and Alonso, R.N. 2007. Biochronology and biostratigraphy of the Uquía Formation (Pliocene-early Pleistocene, NW Argentina) and its significance in the Great American Biotic Interchange. Journal of South American Earth Sciences 23: 1-16.

Reguero, M.A. and Candela, A.M. 2011. Late Cenozoic mammals from the Northwest of Argentina. In: J.A. Salfity and R.A. Marquillas (Eds.), Cenozoic geology of the Central Andes of Argentina. INCE (Instituto del Cenozoico), Salta, p. 411-426.

Rodríguez Brizuela, R. and Tauber, A. 2006. Estratigrafía y mamíferos fósiles de la Formación Toro Negro (Neógeno), Departamento Vinchina, noreste de la provincia de La Rioja. Ameghiniana 43: 257-272.

Rovereto, C. 1914. Los estratos araucanos y sus fósiles. Anales del Museo Nacional de Historia Natural de Buenos Aires 25: 1-247.

Scillato-Yané, G.J. 1979. Notas sobre los Dasypodidae (Mammalia, Xenarthra) del Plioceno del territorio argentino. I. Los restos de Edad Chasiquense (Plioceno inferior) del sur de la provincia de Buenos Aires. Ameghiniana 14: 133-144.

Scillato-Yané, G.J. 1980. Catálogo de los Dasypodidae fósiles (Mammalia, Edentata) de la República Argentina. $2^{\text {do }}$ Congreso Argentino de Paleontología y Bioestratigrafia y $1^{\text {er }}$ Congreso Latinoamericano de Paleontología, (Buenos Aires, 1978), Actas 3: 7-36.

Scillato-Yané, G.J., Krmpotic, C.M. and Esteban, G.I. 2010. The species of genus Chasicotatus Scillato-Yané (Eutatini, Dasypodidae). Revista Mexicana de Ciencias Geológicas 27: 43-55.
Shockey, B.J., Croft, D. and Anaya, F. 2007. Analysis of function in the absence of extant functional homologues: a case study using mesotheriid notoungulates (Mammalia). Paleobiology 33: 227-247.

Soria, M.F. 2001. Los Proterotheriidae (Litopterna, Mammalia), sistemática, origen y filogenia. Monografias del Museo Argentino de Ciencias Naturales 1: 1-167.

Sosic, M.V.J. 1972. Descripción de la Hoja Geológica 14e, Salar de Pipanaco. Dirección Nacional de Geología y Minería, Boletín 137: 1-47.

Tauber, A.A. 2005. Mamíferos fósiles y edad de la Formación Salicas (Mioceno tardío) de la sierra de Velasco, La Rioja, Argentina. Ameghiniana 42: 443-460.

Ubilla, M. and Rinderknecht, A. 2003. A Late Miocene Dolichotinae (Mammalia, Rodentia, Caviidae) from Uruguay, with comments about the relationships of some related fossil species. Mastozoologia Neotropical 10: 293-302.

Urrutia, J.J., Montalvo, C.I. and Scillato-Yané, G.J. 2008. Dasypodidae (Xenarthra, Cingulata) de la Formación Cerro Azul (Miocen tardío) de la provincia de La Pampa, Argentina: Ameghiniana 45: 289-302.

Verzi, D. 1999. The dental evidence on the differentiation of the ctenomyine rodents (Caviomorpha, Octodontidae, Ctenomyinae). Acta Theriologica 44: 263-282.

Verzi, D. and Montalvo, C. 2008. The oldest South American Cricetidae (Rodentia) and Mustelidae (Carnivora): Late Miocene faunal turnover in central Argentina and the Great American Biotic Interchange. Palaeogeography, Palaeoclimatology, Palaeoecology 267: 284-291.

Verzi, D., Montalvo, C. and Vucetich, M. 1999. Afinidades y significado evolutivo de Neophanomys biplicatus (Rodentia, Octodontidae) del Mioceno tardío-Plioceno temprano de Argentina. Ameghiniana 36: 83-90.

Verzi, D.H., Montalvo, C.I. and Deschamps, C.M. 2008. Biostratigraphy and biochronology of the Late Miocene of central Argentina: evidence from rodents and taphonomy. Geobios 41: 145-155.

Villafañe, A.L., Ortiz-Jaureguizar, E. and Bond, M. 2006. Cambios en la riqueza taxonómica y en las tasas de primera y última aparición de los Proterotheriidae (Mammalia, Litopterna) durante el Cenozoico. Estudios Geológicos 62: 155-166.

Vizcaíno, S.F., Fariña, R.A., Zárate, M.A., Bargo, M.S. and Schultz, P. 2004. Palaeoecological implications of the mid-Pliocene faunal turnover in the Pampean Region (Argentina). Palaeogeography, Palaeoclimatology, Palaeoecology 213: 101-113.

Vucetich, M.G., Mazzoni, M.M. and Pardiñas, U.F.J. 1993. Los roedores de la Formación Collón Cura (Mioceno medio), y la Ignimbrita Pilcaniyeu. Cañadón del Tordillo, Neuquen. Ameghiniana 30: 361-381.

Waterhouse, G.E. 1839. Observations on the Rodentia, with a view to point out the groups, as indicated by the structure of the crania in this order of Mammals. Magazine of Natural History 3: 90-96.

Zetti, J. 1972. Observaciones sobre los Pachyrukhinae (Notoungulata) del Plioceno argentino. Publicaciones del Museo Municipal de Ciencias Naturales de Mar del Plata 2: 41-52.

Zittel, K.A. 1893. Handbuch der Palaeontologie, IV. Bd. Vertebrata (Mammalia). R. Oldenbourg, Munich, 590 p.

Zurita, A.E. 2007. [Sistemática y evolución de los Hoplophorini (Xenarthra, Glyptodontidae, Hoplophorinae. Mioceno tardio-Holoceno temprano). Importancia bioestratigráfica, paleobiogeográfica y paleoambiental. Doctoral Thesis, Universidad Nacional de La Plata, 363 p. Unpublished].

doi: 10.5710/AMGH.v49i1(467)

Recibido: $\mathrm{xxx}$

Aceptado: $\mathrm{xxx}$ 